\title{
Notas sobre a Homossexualidade num "Regime de Índio"
}

\author{
Paulo de Tássio Borges da Silva \\ Doutorando em Educação/ UERJ
}

Resumo: A etnologia indígena brasileira pouco tem produzido acerca da homossexualidade, sendo este um tema ainda velado nos relatos etnográficos. Neste sentido, em meio a etnografias desenvolvidas a partir de 2006 até a presente data com o Povo Pataxó (sobretudo do Território Indígena Kaí-Pequi), pretendo manter um diálogo articulando a homossexualidade com a etnicidade, tendo o "regime de índio" como espaço de enunciação na produção de subjetividades e circulação de discursos, tensionando a fixidez e os emolduramentos das identidades no campo das sexualidades.

Palavras-chave: homossexualidade; etnicidade; regime de índio. 


\title{
Notes on Homosexuality in "Indian Regime"
}

\begin{abstract}
The Brazilian ethnology little has produced about homosexuality, which is a topic still veiled in ethnographic accounts. In this sense, amid ethnographies developed from 2006 to date with the Pataxó people (especially the Indigenous Territory Kaí-Pequi) I propousse to maintain a dialogue linking homosexuality with ethnicity, with the "indian regime" as an enunciation space in the production of subjectivities and circulation of speeches, tensionating the fixity and frameworks identities in the field of sexuality.
\end{abstract}

Keywords: homosexuality; ethnicity; Indian Regime.

\section{Notas sobre la homosexualidad un "Régimen de lo Indio"}

Resumen: La etnología brasileña ha producido poco acerca de la homosexualidad, que es un tema todavía velado en informes etnográficos. En este sentido, en medio de etnografías desarrolladas desde 2006 hasta la fecha con la gente Pataxó (sobre todo el Territorio Indígena Kaí-Pequi) si quiere mantener un diálogo vincular la homosexualidad con la etnicidad, con el "régimen indio" como espacio de la enunciación en la producción de subjetividades y circulación de discursos, tensando la fijeza y emolduramentos de las identidades en el campo de la sexualidad.

Palabras-clave: homosexualidad; etnicidad; Régimen de lo Indio. 


\section{Considerações Iniciais}

A pouca produção acerca da homossexualidade na etnologia indígena tem me levado a refletir sobre esta temática, como bem aponta Fernandes (2015), Cariaga (2015), Tota (2013) e McCallum (2013). Para McCallum (2013), "a grande maioria desses trabalhos aborda o gênero na perspectiva da heterossexualidade, sendo a homossexualidade mencionada em alguns poucos casos" (MCCALLUM, 2013: p. 57).1 Neste sentido, partindo de experiências etnográficas com alguns povos da região nordeste há mais de uma década (Pataxó, Tupinambá e Pataxó Hã Hã Hãe), em particular com o Povo Pataxó2, este artigo busca elucidar um diálogo entre homossexualidade e etnicidade.

Minha aproximação com os Pataxó inicia-se no projeto de extensão "A Academia vai à Aldeia: um projeto de intercâmbio intercultural entre os (as) estudantes da UNEB e o Povo Pataxó" em 2006 até o ano de 2011, vindo culminar no Trabalho de Conclusão de Curso - TCC intitulado "A Educação Escolar Indígena no Processo de Revitalização Cultural Pataxó na Escola Estadual Indígena Kijetxawê Zabelê" em 2009. Em seguida passei a atuar como pesquisador especialista pela Fundação do Amparo à Pesquisa do Estado da Bahia - FAPESB, no período de 2010 a 2011, com o projeto "PUTXOP: Pesquisa Intercultural dos Processos- Produtos Educativos Experimentados na Disseminação do Conhecimento Agroecológico e na Revitalização da Etnoeconomia e da Cultura Alimentar Pataxó”. Ao dar seguimento aos estudos acadêmicos realizei a especialização em Educação Infantil na Universidade Estadual do Sudoeste da Bahia - UESB com o TCC "Hãmyá Kitoko Pataxó: trabalho, sociabilidades e agenciamentos entre crianças Pataxó no Território Kaí-Pequi”, onde me propus analisar a relação das crianças Pataxó com as atividades laborais desenvolvidas nas aldeias, seus lócus de agências e espaços de sociabilidades. No mestrado em educação publiquei a dissertação de título "As Relações de Interculturalidade entre Conhecimento Científico e Conhecimentos Tradicionais na Escola Estadual Indígena Kijetxawê Zabelê”, explorando os conhecimentos tradicionais Pataxó. Atualmente me dedico ao doutoramento em educação pelo Programa de Pós-Graduação em EducaçãoPROPED/UERJ, analisando as produções curriculares Pataxó e seus processos de subjetivações, junto ao grupo de pesquisa "Currículo, Subjetividade e Diferença”, sob coordenação da professora Elizabeth Fernandes Macedo. Nesta esteira de formação como pesquisador indigenista, há de se mencionar ainda minha participação como membro do grupo de pesquisa "Educação e Relações Étnicas: saberes e práticas de legado africano e indígenas" no Órgão de Educação e Relações Étnicas com Ênfase em Culturas Afro-brasileiras e Indígenas - ODEERE da Universidade Estadual do Sudoeste da Bahia UESB/CNPQ e no "Núcleo de Pesquisa em Educação, Educação Escolar Indígena e Interculturalidade: experiências entre os povos indígenas Tupinambá, Pataxó e Pataxó Hã Hã Hãe” da UESB/CNPQ.

1 Este artigo deriva de uma comunicação apresentada no VI Congresso Internacional de Estudos sobre a Diversidade Sexual e de Gênero da Associação Brasileira de Estudos sobre a Homocultura - ABEH em 2012, intitulada: "Há lugar para a homossexualidade num 'Regime de Índio'?”.

2 O emprego da categoria povo ao tratar de indígenas é reconhecido pela Convenção 169 da Organização Internacional do Trabalho (OIT), ratificada no Brasil em 1993, admitindo o direito de autodeterminação cultural e étnica nos marcos do Estado brasileiro. 
Neste sentido, é a partir deste itinerário de formação que estarei falando, analisando a homossexualidade a partir do "regime de índio" como espaço de enunciação de produção de subjetividades e circulação de discursos. Como aporte teórico, dialogo com o conceito de "Regime de Índio", entendido como a capacidade de atualizar práticas tradicionais na interação em diferentes arenas culturais, possibilitando uma certa legitimidade étnica (GRÜNEWALD, 1999).

Não estando à procura de fechar o que viria ser uma identidade Pataxó, estarei apresentando abaixo redes discursivas que vem tentado normalizar o que é ser Pataxó, produzindo diferentes textos identitários. Não obstante, vale registrar que qualquer fechamento identitário é impossível, sendo da natureza da subjetivação o escape.

\title{
Os Pataxó e seus fluxos
}

\begin{abstract}
O sujeito é apreensível somente na passagem entre contar/contado, entre "aqui" e "algum outro lugar", e nessa cena dupla a própria condição do saber cultural é a alienação do sujeito (BHABHA, 2013: p. 243).
\end{abstract}

Para falar sobre os Pataxó estarei operando com Appadurai (2004), a partir do seu conceito de mediapaisagem. Para o autor, a mediapaisagem é responsável pela tecelagem de composição do simulacro da discursividade em diferentes tipos de linguagens, "[...] tendem a ser explicações centradas na imagem, com base narrativa de pedaços da realidade, e o que oferecem aos que vivem e as transformam é uma série de elementos (como personagens, enredos e formas textuais) a partir dos quais podem formar vidas imaginadas, as deles próprios e as daqueles que vivem noutros lugares" (APPADURAI, 2004: p. 54). Desta forma, tratando aqui os Pataxó como uma comunidade imaginada, as fixações dadas ao que se é Pataxó nada mais são do que tentativas discursivas de normalização do indeterminado das misturas dos fluxos culturais deste grupo.

Para a linguística e a antropologia, o povo Pataxó pertence ao tronco linguístico Macro-jê e à grande família Maxakali, sendo distribuído em 40 aldeias nos Estados da Bahia, Minas Gerais e Rio de Janeiro, estando 33 aldeias localizadas na Bahia, o6 em Minas Gerais e 01 no Rio de Janeiro3. Os Pataxó são índios Sul-Americanos, brasileiros, conhecidos como Pataxó Meridionais, diferindo-se dos Pataxó Setentrionais, ou Pataxó Hã-hã-hãe, sendo ambos do tronco linguístico Macro-jê e da família Maxakali.

$\mathrm{Na}$ historiografia indígena brasileira, o primeiro relato acerca dos Pataxó são do século XVI. O relato ocorre em 1577, com a entrada de Salvador Correia de Sá, ao encontrar populações Aimoré nas imediações do Rio Doce, e outras nações onde cita como Patachos, Tapuias, Apuris e Puris (EMMERICH \& MONSERRAT, 1975: p. 5). Outro relato é do engenheiro civil Wilhem C. Feldner, em 1813 ao encontrar na Vila do Prado4, capitania de Porto Seguro, um grupo de Maxacali, onde consegue obter dados a partir de informantes Maxacali, quanto aos ritos de enterramento e maneiras de viver. Em 1816, o Príncipe Maximiliam de Wied encontra os Pataxó, já mantendo alianças com os Maxacali. Eis alguns relatos etnográficos apresentados pelo viajante:

3 A aldeia está localizada no município de Angra dos Reis - RJ, com aproximadamente 20 famílias oriundas do Sul da Bahia, tendo o grupo se autodenominado Pataxó Jaguaretê.

4 A Vila do Prado tem uma relação direta com os Pataxó do Monte Pascoal, fundada em 1764, na chamada política pombalina, com o objetivo de proteger a estrada da beira-mar dos inúmeros índios que se refugiavam no sertão do Monte Pascoal, sendo os Pataxó os mais "temidos e perigosos", que se dirigiam à costa do mar, atrapalhando a comunicação e o sossego dos viajantes (CANCELA, 2008: p. 598). 
No aspecto externo, os Patachós assemelham-se aos Puris e aos Machacaris, com a diferença de que são mais altos que os primeiros; como os últimos, não desfiguram rostos, usando os cabelos naturalmente soltos, apenas cortados no pescoço e na testa, embora alguns rapem toda a cabeça e deixem um pequeno tufo adiante e outro atrás. Há os que furam o lábio inferior e a orelha, metendo um pequeno pedaço de bambu na abertura (WIED, 1989: p. 214).

Além dos aspectos físicos relatados por Wied (1989), o mesmo descreve uma cena de negociação entre os Pataxó e os moradores da Vila do Prado em 1810, sendo possível observar desde esta data o escambo Pataxó com os colonos.

Eram tribos Patachós, da qual eu não tinha visto nenhuma até então, e haviam chegado poucos dias antes das florestas, para as plantações. Entraram na vila completamente nus, sopesando armas, e foram imediatamente envolvidos por um magote de gente, traziam para vender grandes bolas de ceras, tendo nós conseguido uma porção de arcos e flechas em troca de lenços vermelhos (WIED, 1989: p. 214).

Para o que vem sendo nomeado de etnohistória Pataxó, segue parte dela contada a partir do mito da criação de seu povo, "Txopai e Itôhã"5.

Antigamente, na terra, só existiam bichos e passarinhos, macacos, caititu, veado, tamanduá, anta, onça, capivara, cutia, paca, tatu, sarigue, teiú, cachichó, cágado, quati, mutum, tururim, jacu, papagaio, aracuã, macuco, gavião, mãe-da-lua e muitos outros passarinhos. Naquele tempo, tudo era alegria. Os bichos $e$ passarinhos viviam numa grande união. Cada raça de bicho e passarinho era diferente, tinha seu próprio jeito de viver a vida.

Um dia, no azul do céu, formou-se uma grande nuvem branca, que logo se transformou em chuva e caiu sobre a terra. A chuva estava terminando e o último pingo de água que caiu se transformou em um índio. $O$ índio pisou na terra, começou a olhar a floresta, os pássaros que passavam voando, a água que caminhava com serenidade, os animais que andavam livremente e ficou fascinado com a beleza que estava vendo ao seu redor. Ele trouxe consigo muitas sabedorias sobre a terra. Conhecia a época boa de plantar, de pescar, de caçar, e as ervas boas para fazer remédios e seus rituais. Depois de sua chegada na terra, passou a caçar, plantar, pescar e cuidar da natureza. A vida do índio era muito divertida $e$ saudável. Ele adorava olhar o entardecer, as noites de lua e o amanhecer.

Durante o dia, o sol iluminava seu caminho e aquecia seu corpo. Durante a noite, a lua e as estrelas iluminavam e faziam suas noites mais alegres e bonitas. Quando era à tardinha, apanhava lenha, acendia uma fogueirinha e ficava ali olhando o céu todo estrelado. Pela madrugada, acordava e ficava esperando clarear para receber o novo dia que estava chegando. Quando o sol apontava no céu, o índio começava o seu trabalho e assim ia levando sua vida, trabalhando e aprendendo todos os segredos da terra.

Um dia, o índio estava fazendo ritual. Enxergou uma grande chuva. Cada pingo ia se transformando em índio. No dia marcado, a chuva caiu. Depois que a chuva parou de cair, os índios estavam por todos os lados. $O$ índio reuniu os outros $e$ falou:

- Olha, parentes, eu cheguei aqui muito antes de vocês, mas agora tenho que partir. Os índios perguntaram:

- Pra onde você vai?

O índio respondeu:

- Eu tenho que ir morar lá em cima no Itôhã, porque tenho que proteger vocês.

Os índios ficaram um pouco tristes, mas depois concordaram.

- Tá bom, mas não se esqueça do nosso povo.

Depois que o índio ensinou todas as sabedorias e segredos falou:

- O meu nome é "Txopai”.

De repente, o índio se despediu dando um salto, e foi subindo, subindo... até que desapareceu, no azul do céu, e foi morar lá em cima no "Itôhã". Pataxó é água da chuva batendo na terra, nas pedras, e indo embora para o rio e o mar. Daquele dia em diante, os índios começaram suas caminhadas aqui na terra, trabalhando, caçando, pescando, fazendo festas e assim surgiu a nação "Pataxó".

5 Mito de criação da Etnia Pataxó. História contada por Apinhaera Pataxó em 1997. In: VALLE, Cláudia Neto do. Sou Brasileiro, Baiano, Pataxó. (Dissertação de Mestrado), PUC-SP, 2000. 
Percebe-se, nos diferentes discursos acima, tentativas de normalização do que vem a ser Pataxó. Vale lembrar que estes compõem uma rede de significados, não estando isolados da ideia de um sujeito nacional. Neste sentido, "o que se interroga não é simplesmente a imagem da pessoa, mas o lugar discursivo e disciplinar de onde as questões de identidade são estratégica e institucionalmente colocadas" (BHABHA, 2013: p. 89). Não obstante,

\begin{abstract}
A representação da diferença não deve ser lida apressadamente como o reflexo de traços culturais ou étnicos preestabelecidos, inscritos na lápide fixa da tradição. A articulação social da diferença, da perspectivas da minoria, é uma negociação complexa, em andamento, que procura conferir autoridade aos hibridismos culturais que emergem em momentos de transformação histórica (BHABHA, 2013: p. 21).
\end{abstract}

A seguir, apresento e discuto a localização territorial do Povo Pataxó, considerando a retomada e a luta pela demarcação de seus territórios como algo legítimo e necessário. Todavia, busco refletir sobre as normalizações em torno da identidade Pataxó no campo da territorialidade, numa análise dos discursos que estão circulando e sendo negociados neste contexto, de modo a não fixar tal identidade.

Segundo etnografias e historiografias os Pataxó sempre estiveram no litoral baiano, vivendo como coletores. Contudo, é registrado na história indígena Pataxó o chamado "Fogo de 1951", um esfacelamento do último aldeiamento deste grupo por forças policiais e pistoleiros de fazendeiros na região, o que levou ao que é conhecido como diáspora Pataxó, explicando a presença do grupo em Minas Gerais (SILVA, 2014). Cabe dizer, que a desterritorialidade Pataxó nem sempre é bem vista, uma vez que a política identitária brasileira trabalha com uma noção emoldurada de território, sendo este considerado um capilar compulsório de identidades.

Tal questão pode ser observada na dificuldade de indígenas serem reconhecidos enquanto tal, quando ultrapassam as linhas imaginadas do território tido como "imemorial”. Em etnografias realizadas com o grupo Pataxó do Território Kaí-Pequi6 (também campo etnográfico desta reflexão deste artigo), acompanhei as idas e vindas da Cacica Ariã à FUNAI para reconhecimento de sua aldeia, conhecida como "Aldeia Cumuru", uma aldeia urbana que reunia famílas Pataxó que moram no distrito de CumuruxatibaPrado-Bahia. A busca de reconhecimento da aldeia se concentrava no acesso às políticas de saúde e educação diferenciadas, uma vez que os Pataxó residentes no distrito não possuem direito a tais políticas, sendo estas pautadas para índios aldeados fora do perímetro urbano. A tentativa de reconhecimento foi frustrada, tendo exigido a FUNAI que os (as) indígenas estivessem reunidos (as) em uma aldeia fora do perímetro urbano. A Cacica criou a Aldeia Dois Irmãos, estando esta dentro do território imaginado Comexatibá, conhecido também por KaíPequi. Território este reconhecido e delimitado em laudo antropológico por equipe técnica da FUNAI. Para Bhabha (2013),

\footnotetext{
As diferenças sociais não são simplesmente dadas à experiência através de uma tradição cultural já autenticada; elas são os signos da emergência da comunidade concebida como projeto - ao mesmo tempo uma visão e uma construção - que leva alguém para "além" de si para poder retornar, com um espírito de revisão e reconstrução, às condições políticas de presente: (BHABHA, 2013: p. 22).
}

6 O Povo Pataxó está localizado em três territórios. O Território de Barra Velha, o Território de Coroa Vermelha e o Território Kaí-Pequi, também conhecido como Território de Comechatibá, além de aldeias em Minas Gerais e Rio de Janeiro. Os Pataxó que este artigo trata são do Território Kaí-Pequi. 
Vemos que em contextos de despossessão dos direitos básicos, como saúde e educação, a reiteração da norma se dá, como aponta Bhabha (2013), às condições políticas do presente, "os fragmentos, retalhados e restos da vida cotidiana devem ser repetidamente transformados nos signos de uma cultura nacional coerente, enquanto o próprio ato da performance narrativa interpela um círculo crescente de sujeitos nacionais (BHABHA, 2013: p. 237). No entanto, aceitar localizar-se dentro de um território não significa que os rompimentos não estão se dando, o que pode levar a pensar que o jogo está dado. As famílias continuarão se deslocando, mesmo compactuando a priori, à ideia de estarem dentro de um território indígena pactuado com/pelo o Estado.

A partir do caso da Aldeia Dois Irmãos, podemos então problematizar, que o território também é imaginado e alicerçado discursivamente por dispositivos geopolíticos de controle das territorialidades e fins de governabilidade (laudos antropológicos, etnografias e censos). Contudo, esta discursividade nunca está fechada, sendo composta de uma variedade de etnopaisagens por grupos e indíviduos que dão outros sentidos às suas vidas e mundos.

No caso Pataxó do Território Comexatibá, localizado no Extremo Sul da Bahia, Cumuruxatiba/Prado- Bahia, o controle do Estado-nação tem se dado com a criação de uma Unidade de Conservação Integral, o Parque Nacional do Descobrimento- PND, sobresposto ao território delimitado como Pataxó pela FUNAI. A princípio a sobreposição pode não apresentar nenhum problema, no entanto, o Sistema Nacional de Unidades de Conservação - SNUC, legislação que regula os parques, traz como norma que em Unidades de Conservação Integral a presença humana não é permitida. O que nos leva a crer que o reconhecimento do direito à reprodução material e imaterial dos indígenas em seu território, garantindo pela Constituição Federal nos seus artigos 231 e 232, é remodelado pelos fluxos culturais Pataxó em seus processos de desterritorialização, bem como em novos dispositivos bio-geopolíticos regulamentados pelas Unidades de Conservação.

O interessante é que mesmo com o poder de controle estatal, os escapes são fluxos contínuos. Isto porque o poder também pode ser tratado no campo do imaginário, do perspectivado - não negando aqui a materialidade de um poder militar, por exemplo. Neste sentido, tratar o poder como algo imaginado é perceber o mesmo numa fronteira de discursividades, com vácuos de fronteiras possíveis na composição de etnopaisagens de fabricação de sujeitos, etnias, nações, gênero, sexualidades, entre outros. É pensar o imaginado numa lógica do improviso, do não pronto, do caminho a tornar-se.

\section{Homossexualidade e Etnicidade}

Ao escrever sobre perversão no livro "Sexo e Repressão na Sociedade Selvagem”, Bronislaw Malinowski (1973) fala de sua experiência nas Trobriand, lamentando não ter sido possível estudar o assunto com detalhes. Segundo o autor, "a homossexualidade é conhecida como existente em outras tribos, sendo considerada uma prática asquerosa e ridícula. Apareceu nas Trobriand somente com a influência dos brancos, mas especialmente da moralidade dos homens brancos" (MALINOWSKI, 1973: p. 84). Neste sentido, Malinowski (1973) coloca a homossexualidade como sendo uma característica dos não-indígenas remetendo à moralidade destes, no caso das Trobriand teria aparecido por conta da missão onde ficaram isolados rapazes e moças e desta forma "[...] tiveram que valer-se a si mesmos da melhor maneira que puderam, uma vez que aquilo 
que qualquer habitante das ilhas considerava como sendo justo e natural lhes era negado" (MALINOWSKI, 1973: p. 85). Para não se fazer uma abordagem anacrônica, é preciso levar-se em conta que o texto de Malinowski foi escrito em 1927 durante sua experiência com os Trobriandeses7. Nesta esteira de análise é necessário localizar na época o campo de representações acerca da homossexualidade. Ainda refletindo sobre os apontamentos Malinowskianos, o mesmo nos apresenta na obra o conceito de "plasticidade dos instintos". Segundo Malinowski (1973),

\begin{abstract}
Em vez dos determinantes instintivos exatos temos elementos culturais que modelam as tendências inatas. Tudo isto implica uma profunda modificação na relação entre instinto e processo fisiológico e a modificação de que são capazes. Denominamos esta alteração "plasticidade dos instintos" [...] Essa plasticidade está associada com a efetiva determinação do comportamento sexual por elementos culturais. O homem é dotado de tendências sexuais, mas estas têm de ser moldadas além disso por sistemas de regras culturais, que variam de uma sociedade para outra (MALINOWSKI, 1973: p. 169, 189).
\end{abstract}

É na cultura que a sexualidade é moldada de acordo com as suas cosmologias, regras, pactos sociais, dentre outras convenções. É a cultura a responsável pela modelagem dos corpos e das sexualidades, legitimando quais as identidades sexuais devem ser aceitas e determinando aquelas que passam a ser marginalizadas.

Clastres (1978) ao pesquisar os Guaiaqui traz dados etnográficos sobre Krembégi, um indígena em que o autor nomeia de homossexual.

\begin{abstract}
Krembégi era na verdade um sodomita. Ele vivia como as mulheres e, à semelhança delas, mantinha em geral os cabelos nitidamente mais longos que os outros homens, e só executava trabalhos femininos: ele sabia "tecer" e fabricava, com os dentes de animais que os caçadores lhe ofereciam, colares, que demonstravam um gosto e disposições artísticos muito melhor expressos do que nas obras das mulheres. Enfim, ele era evidentemente proprietário de um cesto. Em suma, Krembégi atestava assim no seio da cultura Guaiaqui a existência inesperada de um refinamento habitualmente reservado a sociedades menos rústicas. Esse pederasta incompreensível vivia como uma mulher e havia adotado as atitudes e comportamentos próprios desse sexo. Ele recusava por exemplo tão seguramente o contato de um arco como um caçador, o do cesto; ele considerava que seu lugar natural era o mundo das mulheres. Krembégi era homossexual porque era panema. (CLASTRES, 1978: p. 76).
\end{abstract}

Nota-se no relato de Clastres (1978) uma ideia de vinculação da homossexualidade às sociedades não indígenas (sociedades menos rústicas). $\mathrm{O}$ autor remete o fato de Krembégi ser panema (mal caçador) estar atrelado à sua condição de homossexual, conhecido pelos demais Guaiaqui como "[...] um kyrypy-meno (ânus-fazer amor) porque era panema” (CLASTRES, 1978: p. 77). Para Clastres (1995),

[...] não há, nenhum terceiro-espaço para abrigar os que não são nem do arco nem da cesta. Cessando de ser caçador, perde-se por isso mesmo a qualidade de homem, virase, metaforicamente, uma mulher. Eis o que compreendeu e aceitou Krembégi; sua renúncia radical ao que é incapaz de ser - caçador - projeta-o de imediato do lado das mulheres, ele está em casa entre elas, ele se aceita mulher. (CLASTRES, 1995: p. 212).

Vale dizer que, na análise apresentada por Clastres (1978, 1995) Krembégi se subjetiva como homossexual pelo fato de ser panema, o que não se destina a todos os Guaiaqui mal caçadores. Neste caso, temos

7 Os Trobriandeses são nativos das ilhas Trobriand, na costa oriental da Nova Guiné, região banhada pelo Oceano Pacífico. A principal ilha do arquipélago de $440 \mathrm{Km}^{2}$ é Kiriwina. Malinowski residiu por muitos anos entre os trobriandeses, objeto de seu estudo publicado no livro "Argonautas do Pacífico Ocidental". 
Chachubutawachugi, também panema, viúvo, que por ter azar na caça, lhe era impedido o acesso às mulheres, perdendo parcialmente sua qualidade de homem (CLASTRES, 1978: p. 76). Chachubutawachugi não transitava nas redes de sociabilidades dos homens Guaiaqui, mas, diferentemente de Krembégi, a homossexualidade não fazia parte de sua condição, o que coloca esta na ordem da agência dos Guaiaqui mal caçadores, e não como condição.

Em seus estudos etnohistóricos sobre a América Pré-Colombiana, Mott (1998) nos mostra a diversidade sexual presente entre os Maias, que "[...] prestavam culto ao amor unissexual" (MOTT, 1998: p. 3), sendo que na América do Sul "[...] região dos Andes, foram encontradas provas arqueológicas confirmando a prática do homoerotismo antes da chegada dos europeus. Há notícia que os espanhóis teriam igualmente no Peru encontrado e derretido esculturas em ouro representando cópula anal entre dois homens (MOTT, 1998: p. 4). Se referindo aos Povos Indígenas brasileiros, Mott (1998) diz que "entre os Tupinambá que ocupavam a maior parte da costa brasileira, os índios gays eram chamados de Tibira, e as lésbicas de caçoaimbeguira” (MOTT, 1998: p. 14). Quanto aos Guaicuru, etnia pertencente à nação Guarani e residentes às margens do Rio Paraguai, encontravam-se no século XVIII índios que se travestiam, como segue o relato abaixo:

\begin{abstract}
Entre os Guaicurus e Xamicós, há alguns homens a que estimam e são estimados, a que se chamam cudinhos, os quais lhe servem como mulheres, principalmente em suas longas digressões. Estes cudinhos ou nefandos demônios, vestem-se e se enfeitam como mulheres, falam como elas, fazem só os mesmos trabalhos que elas fazem, trazem jalatas, urinam agaxados, têm marido que zelam muito e tem constantemente nos braços, prezam muito que os homens os namorem e uma vez cada mês, afetam o ridículo fingimento de se suporem menstruados, não comendo mulheres naquela crise, nem peixe nem carne, mas sim de algum fruto e palmito, indo todos os dias, como elas praticam, ao rio, com uma cuia para se lavarem (MOTT, 1998: p. 16, negritos do original).
\end{abstract}

Trevisan (1986), fazendo algumas considerações sobre o Povo Krahó, pertencente ao Tronco Linguístico Macro- Jê e à família Jê, no Estado do Tocantins, aponta que os homens solteiros e casados desta etnia realizam práticas homoeróticas. Para Trevisan (1986), há a "[...] crença de que, no Brasil, os índios contraem gripe, doenças venéreas e homossexualismo no contato com os brancos" (TREVISAN, 1986: p. 96), conforme o pensamento Malinowskiano ao analisar a homossexualidade com os Trobriandeses.

Com os Huni Kuin (Kaxinawá), McCallum (2013) relata em etnografia ter ouvido "[...] uma história sobre homens vestidos de mulheres vistos em Pucallpa - chamados de 'maricones', que faziam sexo com outros homens, que suscitava risos e certa incredulidade” (MCCALLUM, 2013: p. 54). A autora chama atenção para o fato de tais conversas não serem comuns, sendo mais frequente histórias sobre sexo entre animais e humanos (MCCALLUM, 2013).

Em análises acerca da homossexualidade desenvolvidas no projeto "Sexualidade e conjugalidade entre pessoas do mesmo sexo na aldeia e na cidade”, nas aldeias Japirú e Bororó no Mato Grosso do Sul, Cancela, Silveira e Machado (2010) observam que ao chegar a campo muitas pessoas foram citadas como homossexuais, contudo ao conversar com estas pessoas citadas, as mesmas não se identificavam como tal, afirmando que ouviam dizer que havia na aldeia, chegando à conclusão da existência de um "[...] jogo de (in) visibilidade existente nas aldeias e a percepção de que estes envolvimentos estavam marcados por tensões" (CANCELA; SILVEIRA; MACHADO, 2010: p. 207), bem como piadas. 
No contexto dos "Índios do Nordeste", Tota (2013) apresenta em seus trabalhos etnográficos com os Potiguara na Baía da Traição, situada no litoral Norte da Paraíba, o que chama de cenários de homossociabilidades. Ao analisar onde se cruzam etnicidade e sexualidade, o autor coloca que:

[...] noções de raça estiveram desde sempre imiscuídas em preceitos religiosos, nos ideais de soberania e civilização, nas imagens estereotipadas das sexualidades dos povos autóctones e o quanto a regulação e o disciplinamento dessas sexualidades eram importantes para os projetos de conquista e, posteriormente, para a formação de um Estado-Nação. Neste contexto, também a "sodomia" foi acionada pelos conquistadores ibéricos como justificativa para subjugar as populações ameríndias (TOTA, 2013: p. 337).

Nesta relação, Tota (2013) evidencia que entre os indígenas do Nordeste, neste caso os Potiguara, a reificação do étnico em detrimento do silenciamento das questões de gênero e sexualidades, perpassa a construção de um "índio hiper-real", em que "certamente muitas lideranças de coletividades indígenas não veem nenhuma vantangem em ter os etnôminos que representam associados a indivíduos cujos comportamentos escapam à heteronormatividade" (TOTA, 2013: p. 339).

Em sua pesquisa de doutorado intitulada "Decolonizando Sexualidades: enquadramentos coloniais e homossexualidade indígena no Brasil e nos Estados Unidos”, Fernandes (2015) parte das críticas do movimento indígena queer norte-americano (Two Spirits) e de perspectivas decoloniais para dizer dos enquandramentos das sexualidades e colonização dos Povos Indígenas nos dois contextos de sua pesquisa. Desta forma:

\begin{abstract}
Como vimos, lá, como cá, houve momentos marcados por missões, integração forçada, deslocamentos forçados, escolas que buscassem "civilizá-los" compulsória e rapidamente. Da mesma forma, o enquadramento das sexualidades indígenas seguiu um percurso bastante similar: o manejo moral dos povos indígenas, seja por meio de castigos ou de imposição de nomes próprios, padrões de divisão de trabalho baseados em binarismo sexual, ou educação, era parte fundamental de sua incorporação compulsória ao sistema colonial. Entendo que mesmo em diferentes contextos nacionais, ambos estivessem sujeitos às mesmas ordens discursivas, sendo compulsoriamente colonizados em suas sexualidades a partir de projetos nacionais, civilizatórios, religiosos, integracionistas e enquadramentos diversos que buscassem criar e manter a diferença colonial (FERNANDES, 2015: p. 287-288).
\end{abstract}

O trabalho de Fernandes (2015) tem sido potente ao elucidar de forma comparativa os dispositivos da empresa colonial na regulação dos modos de ser indígenas, bem como ao trazer a contribuição da teoria decolonial e o Two Spirit como possibilidades de resistências e escapes.

Cariaga (2015), em etnografias e entrevistas com os jovens Kaiowa e Guarani no Mato Grosso do Sul, coloca como a homossexualidade tem modificado as relações na Reserva Indígena de Dourados - RID, sendo a opção morar na cidade uma alternativa na mediação de conflitos para jovens que se identificam como homossexuais. Na esteira do que foi apontado acima por Trevisan (1986), segundo Cariaga (2015):

A ideia de que a homossexualidade é um traço cultural dos brancos, que não pode ser vista como uma prática sexual comum entre os Kaiowa, permeia parte das reflexões e é também produzida a partir da adesão a igrejas evangélicas e neopetencostais, que têm muitos fiéis e produzem ascendência política sobre os moradores da RID, visto que há muitas famílias que seguem as doutrinas religiosas que tratam o assunto como pecado ou desvio de conduta (CARIAGA, 2015: p. 446). 
Não obstante, apesar de ir para a cidade ser uma alternativa para estes jovens, o dilema está dado em viverem afastados do modo de ser Kaiowa e Guarani (ñande reko), uma vez que precisam estar distantes do cotidiano das aldeias. Neste sentido, o prestígio social a estes jovens passa a ser dado por outras instâncias, como ser funcionário público e arcar com as despesas das famílias nas aldeias (CARIAGA, 2015).

\section{Os Pataxó e o Regime de Índio: há lugar para a homossexualidade?}

Em etnografias construídas com os Pataxó do Território Kaí-Pequi a partir de 2006 até a presente data, como foram elencadas algumas vivências acima, nasceu a presente reflexão ao se observar os jogos de negociação entre o Povo Pataxó e os não indígenas. Era comum durante conversas com um ou outro nas aldeias ou nas cidades, ouvir dizer que fulano era "gay" e fulana "sapatão", ou simplesmente "ele fica com homem", "ela fica com mulher" ou entre risadas dizer é "Manãy"8. Contudo, mesmo entre as fofocas e as risadas parecia haver um certo acordo entre o grupo, onde todos sabiam, mas evitavam comentar, sobretudo com os não-indígenas. Acerca da função social da fofoca, Barbard e Spancer (1996) fazem as seguintes considerações:

[...] a fofoca é o modo pelo qual os indivíduos alinham suas ações: negociam entre si o escopo e a importância de regras culturais e comportamentos sociais os quais eles põem em prática. Fofoca é, em sua essência, um processo meta- cultural: uma atividade pela qual os indivíduos examinam e discutem juntos as regras e as convenções sob as quais eles vivem. Além disso, a partir do momento em que as regras são relativas e ambíguas em sua aplicação, a interpretação nunca é final ou consensual. Por essa razão, a fofoca continuamente desmembra, avalia e reconstitui o mundo todos os dias (BARBARD \& SPANCER, 1996: p. 267).

Vanzolini (2015) ao estudar os Aweti do Alto Xingu, sugere a fofoca como um dos elementos engendradores nos processos de identificação e diferenciação, ao lado da feitiçaria.

A circulação de histórias, que torna as pessoas conhecidas umas das outras, e logo parentes, é por vezes o que impõe sua diferença, na medida em que são recebidas como histórias dos outros, fofocas. Elas são o correlato discursivo dos objetos que se constituem, por um lado, como meios de fazer parentes e, por outro, meios de desfazê-los, amarrados no feitiço (VANZOLINI, 2015: p. 344).

Cariaga (2015) com os Guarani e Kaiowá da RID, menciona o papel da fofoca na relação de fabricação da vida íntima e social.

[...] a fofoca entre os moradores da RID impulsiona ações e movimentos políticos entre as famílias extensas, como trocas de lideranças, mudanças nos cargos políticos nas agências governamentais, transferência de domicílio, acusações de feitiçaria, que costumeiramente pairam sobre os homens solteiros e deconectados de fogos domésticos (CARIAGA, 2015: p. 448).

No que se relaciona à homossexualidade indígena, Cariaga (2015) coloca que morar na cidade "[...] é um meio de mediar as tensões inerentes a situações em que a homossexualidade pode circular como fofoca" (CARIAGA, 2015: p. 448).

Neste sentido, no jogo de negociação dissimulado a partir da fofoca, são veiculadas as permissões, os silenciamentos e os interditos dos lugares da 
homossexualidade dentro do grupo étnico. Para os Pataxó, a fofoca além de ser um elemento em que enuncia a diferença, é um dispositivo de controle e proteção do que destoa e não cabe dentro do chamado "índio hiper-real"9, bem como elemento construtor do "regime de índio".

Ao acompanhar grupos de Pataxó em eventos e feiras onde os (as) mesmos (as) eram convidados (as) a exporem seus trabalhos, artesanatos e ministrarem oficinas, era constante a pergunta dos (as) não indígenas acerca do trato à homossexualidade nas aldeias. A pergunta na maioria dos casos vinha com um aspecto de curiosidade, acompanhada de uma possível explicação para a compreensão da homossexualidade nas sociedades não indígenas. No primeiro momento reinavam-se alguns segundos de silêncios após a pergunta, onde os Pataxó se entreolhavam, alguns davam um sorriso para o outro numa espécie de autorização para que o outro respondesse a pergunta. A resposta sempre era a mesma “[...] não tem isso lá não" ou “[...] se tem a gente não sabe”. Numa certa oportunidade ao partilhar uma conversa desta, após a saída do interlocutor que fez a pergunta, indaguei dois Pataxó e perguntei por que tinham dito que não havia homossexuais entre eles, uma vez que eu e eles tínhamos conhecimento de algumas pessoas, a resposta foi a seguinte: "[...] estas coisas a gente deixa entre nós".

Acompanhando a conversa também havia uma Pataxó que observava como se dava o diálogo entre os seus "parentes" e o grupo de não indígenas. Logo depois presenciei uma conversa da mesma com os dois Pataxó onde ela dizia: "[...] que mulher besta, tanta coisa pra perguntar e ela fica perguntando estas coisas, tinha que falar que tem sim, onde é que não tem? Isto existe é em todo lugar".

Pode-se observar, neste sentido, que a homossexualidade é negociada e velada diante do (a) não indígena, imperando o que Grünewald (1999) chama de um "regime de índio". Nesta perspectiva é preciso dizer o que o (a) outro (a) deseja ouvir, no campo de suas representações do que é ser índio. Acerca deste ponto voltamos a Trevisan (1986) e Cariaga (2015), na ideia de que a homossexualidade seria adquirida pelo contato com o (a) não indígena. Neste mesmo itinerário de reflexão, existir homossexualidade em determinado grupo étnico, seria dizer que este estabelece contato com a sociedade não indígena, o que do ponto de vista de uma abordagem cultural essencialista de uma cultura fixa diminuiria a identidade étnica deste grupo. Na incorporação desta análise apontada por Trevisan (1986) e Cariaga (2015), observei que fora das aldeias a presença dos (as) Pataxó que são reconhecidos por práticas homoafetivas é mais frequente, ficando estes (as) mais nas cidades, indo para a aldeia apenas em ocasiões especiais ou em visitas às famílias. Sendo possível ouvir falas como "[...] ele é, mas fica mais na cidade”. Acerca da presença destes (as) na cidade, não tive a oportunidade de investigar para saber qual foi a condição de se estar na cidade, se foi por vontade própria, ou por pressão da família e da comunidade. Contudo, tomo como hipótese o que Cariaga (2015) vem apontando em suas pesquisas com jovens homossexuais Guarani e Kaiowá na RID em Mato Grosso do Sul.

\section{Considerações Inconclusas}

9 A ideia de "índio hiper real" se refere a um indígena verdadeiro, que desepenha o papel que os não indígenas lhe atribuem , que apresenta pureza ideológica, morre defendendo seu território e que resiste atravessar a fronteira da tradição (FONSECA, 2004: p. 115). 
Voltando-se às questões que nortearam este trabalho é possível perceber que não há lugares para a homossexualidade indígena num "regime de índio", uma vez que este se estabelece numa relação de poder em que o "dominador" estabelece uma tipologia ideal de indianidade, tendo o "dominado" que se adequar a esta na possibilidade de acessos que este pode proporcionar (políticas públicas, programas, dentre outros). Contudo, é possível se pensar relações que proporcionem uma construção cultural Pataxó que vá além das internalizações sexistas e homofóbicas presentes e legitimadas no "regime de índio". Para tanto, faz-se necessária a desconstrução deste bloco de indianidade homogêneo, levando-se em conta as particularidades de cada etnia, suas cosmologias e hibridizações dentro deste tecido cultural enviesado no cotidiano de suas relações e atividades.

\section{Referências Bibliográficas}

APPADURAI, Arjun. Dimensões Culturais da Globalização: a modernidade sem peias. Lisboa: Editorial Teorema LTDA, 2004 (Trad. Telma Costa).

BHABHA, Homi K. O Local da Cultura. 2 ed. Belo Horizonte: Editora UFMG (trad. Myriam Ávila, Eliana Lourenço de Lima Reis, Gláucia Renate Gonçalves), 2013 .

BARBARD, Alan; SPANCER, Jonathan. Encyclopedia of Social and Cultural Anthropology. London. New York: Routledge, 1996.

CANCELA, Cristina Donza; SILVEIRA, Flávio Leonel Abreu da; MACHADO, Almires. Caminhos de uma Pesquisa acerca da Sexualidade em Aldeias Indígenas no Mato Grosso do Sul. In: Revista de Antropologia. São Paulo: USP, v. $53, \mathrm{n}^{\circ} .1,2010$.

CANCELA, Francisco. Uma barreira contra os perigos do sertão do Monte Pascoal: a criação da vila do Prado, os índios Pataxó e a ressignificação das relações de contato (1764-1820). In: CAETANO DA SILVA, José Luís; CARVALHO, Maria do Rosário. G.; AGOSTINHO, Pedro (Orgs.). Tradições étnicas entre os Pataxó no Monte Pascoal: subsídios para uma educação diferenciada e práticas sustentáveis. 1ed.Vitória da Conquista: Edições UESB, 2008, v. 1, p. 598-616.

CARIAGA, Diógenes. Gênero e Sexualidades Indígenas: alguns aspectos das transformações nas relações a partir dos Kaiowa no Mato Grosso do Sul. In.: Cadernos de Campo. São Paulo, n. 24, p. 441-464, 2015.

CLASTRES, Pierre. O Arco e o Cesto. In.: CLASTRES, Pierre. A Sociedade contra o Estado: pesquisas de antropologia política. Rio de Janeiro: Francisco Alves, p. 71-89, 1978.

. Crônica dos Índios Guayaki: o que sabem os Aché, caçadores

nômades do Paraguai. Rio de Janeiro: Ed. 34 , 1995. 
EMMERICH, Charlotte; MONSERRAT, Ruth. Sobre os Aimorés, Krens e Botocudos: novas linguísticas. In: Boletim do Museu do Índio, Antropologia, no. 3, Rio de Janeiro, 1975.

FERNANDES, Estevão Rafael. Descolonizando Sexualidades: enquadramentos coloniais e homossexualidade indígena no Brasil e nos Estados Unidos. Brasília: Programa de Pós-Graduação em Estudos Comparados sobre as Américas (Tese de Doutorado), 2015.

FONSECA, Claudia. Família, Fofoca e Honra: etnografia de relações de gênero e violência em grupos populares. 2 ed.. Porto Alegre: Editora da UFRGS, 2004.

GRÜNEWALD, Rodrigo de Azeredo. Os "Índios do Descobrimento": tradição e turismo. Rio de Janeiro: UFRJ/MN/PPGAS (Tese de Doutorado), 1999.

MCCALLUM, Cecília. Notas sobre as categorias "gênero" e "sexualidade" e os povos indígenas. In.: Cadernos Pagu, n. 41, p. 53-61, 2013.

MALINOWSKI, Bronislaw. Sexo e Repressão na Sociedade Selvagem. (Tradução de Francisco M. Guimarães) Petrópolis: Vozes, 1973.

MOTT, Luiz. Etno-História da Homossexualidade na América Latina. In: História em Revista. Pelotas, v. 4, p. 7- 35, 1998.

SILVA, Paulo de Tássio Borges da. Há lugar para a homossexualidade num "Regime de Índio"? In: Anais do IV Congresso de Estudos sobre a Diversidade Sexual e de Gênero da ABEH. Salvador: UFBA, 2012.

As Relações de Interculturalidade entre Conhecimento Científico e Conhecimentos Tradicionais na Escola Estadual Indígena Kijetxawê Zabelê. Rio de Janeiro: Editora Multifoco, 2014.

TOTA, Martinho. Entre as Diferenças: Gênero, geração e sexualidades em contexto interétnico. Rio de Janeiro: Multifoco, 2013.

TREVISAN, João Silvério. Devassos no Paraíso: a homossexualidade no Brasil, da Colônia à atualidade. 2 ed. São Paulo: Max Limonad, 1986.

VALLE, Cláudia Neto do. Sou Brasileiro, Baiano, Pataxó. São Paulo: PUC-SP, 2000. (Dissertação de Mestrado).

VANZOLINI, Marina. A flecha do ciúme: o parentesco e seu avesso segundo os Aweti do Alto Xingu. São Paulo: Terceiro Nome, 2015.

WIED-NEUWIED, Maximiliano. Viagem ao Brasil. Belo Horizonte, Itatiaia; São Paulo: EDUSP, 1989. 